\title{
Indonesian Folklore Based on Gender Equality to Improve Literacy Culture
}

\author{
Dase Erwin Juansah*, Ade Husnul Mawadah, Ade Anggraini Kartika Devi \\ Indonesia Language Education \\ Universitas Sultan Ageng Tirtayasa \\ Serang, Indonesia \\ *daserwin77@untirta.ac.id, adehusnul@untirta.ac.id, adekartikadevi@untirta.ac.id
}

\begin{abstract}
The content of folklore that contains gender equality can improve mutual respect without looking down on gender. This study aims to describe and reconstruct the folklore of Indonesia from a gender equality perspective. The research method used was based on a qualitative paradigm with a descriptive model. The data were collected through the observation method followed by note-taking technique. The data analysis technique was done by analysing the image of women in existing folklore, reconstructing folklore from a gender equality perspective, and designing narratives and visuals of the folklore. Folklore reconstruction produces stories that do not weaken the female figure. This research shows that the ideology of folklore can be adapted to the values that want to be taught to the younger generation. Certainly, the reconstruction does not change the story line, but takes the opposite point of view.
\end{abstract}

Keywords—folklore, gender equality, literacy

\section{INTRODUCTION}

Cultural cultivation is an important issue for the character building of the nation's children. Character is formed by values that are selected, cultivated, and consistently realized in action. In the world of education in Indonesia, instilling positive things in learning is a powerful way to shape student character. The expected character is a positive character indeed, so that in the end students become individuals who are not only intelligent in the brain, but also intelligent on behaviour. In other words, when someone is recognized as having a good character as it is commonly used, that person also possesses some other character such as trustworthiness, integrity, passionate, reliable, and dependable [1].

Regarding on it, the teacher uses various learning strategies to create students with positive character. Among these strategies are reading together and telling stories. These strategies are also in line with efforts to improve literacy culture in schools because literacy involves productive (e.g., writing, speaking) as well as receptive (e.g., reading, listening) [2]. Therefore, reading to children has been identified as one of the principal early literacy behaviours that parents or teacher can engage in to advance their children's literacy development.
Literacy culture is the spirit contained in the 2013 Curriculum. Students are expected to have good oral and written communication skills. If students have the ability to communicate verbally and in writing well, it can be said that these students have achieved good literacy skills. To be able to have this ability, teachers and students need to design activities that improve literacy skills. One of the efforts that can be made by the teacher is to continuously build a literacy atmosphere in the learning process. This should be a special time, so the teacher should make sure that students enjoy the story [3].

To support student literacy skills, teachers must be able to select the right reading material [4]. Teachers can choose reading materials such as choosing books that are attractive to children and have content related to the curriculum. Based on these criteria, folklore can be used to improve literacy culture while shaping the character. In addition, folklore is one of the materials contained in the 2013 Curriculum in elementary schools. Through reading folklore, children will not only obtain knowledge, but also more empathy [5].

Folklore is an effective medium to cultivate and shape children's character. Folklore is an important medium for the development of moral and ethical values in children because the moral lessons and the cultural values to be learnt from tales and are innumerable and unquantifiable [6].

Folklore as part of culture contains various ideas and it is full of values that are useful for nation building. Folktales have the following advantages, such as sensitize children to the immediate environment, increase the children's patriotism, and enhance moral development [7]. Folklore gives children the opportunity of using their imagination to interpret the truth and develop their intellect. Folklore also has a didactic purpose, that is teaching morals or values that apply in society which are reflected through the characters presented in the story. It is not excessive to say that because folklore is a legacy of the minds of the nation's ancestors.

However, the ideology of folklore is not always in accordance with the values that want to be taught to the younger generation. There are gender stereotypes blended in folklore. There are folklore which weaken the position of 
women and tend to objectify women. Research from South Africa found that female characters in folklore were often seen as muted and peripheral [8]. Hapsarani supports this inequality with the results of her research on the objectivization of women in the folktale of Si Leungli, Jaka Tarub, and Sangkuriang. Women are shown as an object of pleasure, abuse, and even as an object of male violence [9]. Women are shown to be powerless and weak so that they are easily tricked by men, while men are shown to be dominant and have power over women. Women are also shown as objects of male violence and at the same time need men to help them. In other hand, Indonesian folklore show that the figure of woman must be glamorous, behave kindly and gently, honourable character, and skilled in domestic area [10]. Moreover, in a folktale, a nice woman is one who behaves subservient and waits for her prince to save her life her while a woman who is having mightiness often depicted as an evil and ugly character [11]. So, that both parents and teachers should be aware of the influence of misleading children's literature and the extent to which folklore impact on the development of children's concepts [12].

Terminologically, gender is defined as cultural expectations of men and women. is related to the ideology behind the human mindset to make rules in social life. Gender concerns on feminine and masculine. Since centuries ago, gender has influenced human to form a patriarchal cultural structure.

In fact, gender equality values are an important part of character building because respect and synergy between people are a real form of Indonesian culture. Thus, "Indonesian Folklore based on Gender Equality to Improve Literacy Culture in Elementary Schools" is important to be researched. Reading story with children over a sustained period of time can shapes children's gender attitudes and beliefs [13]. Literacy culture, especially in elementary schools, requires positive media that can instil character values, love Indonesian culture, respect each other and synergize among humans.

\section{METHODS}

This research uses a qualitative approach. Through a qualitative approach, researcher creates a complex picture, examines words, does detail reports from the respondent's point of view, and conducts studies on natural situations [14]. The method used in this research is descriptive method.

The research design used is content analysis. Content analysis allows researchers to study human behaviour [15]. This design is used to analyse gender equality which can be seen from the attitudes, views, and images of both male and female characters in folk stories. Bawang Putih Bawang Merah, Sangkuriang, and Lutung Kasarung are folk tales used in this study.

The data are collected using the listening technique and then classified based on the required characteristics, such as the attitudes, views, and images of the characters. Then the data are interpreted, and a new story is created from the perspective of gender equality.

\section{RESULTS AND DISCUSSION}

Based on the research results, women in the folktale of Bawang Putih Bawang Merah, Sangkuriang, and Lutung Kasarung are told from a man perspective. Dayang Sumbi is depicted as a woman with a beautiful, cute, and youthful character, but rash, weak, and irrational. Purbasari is portrayed as a helpless woman because she resists accepting an accusation of carrying infectious skin diseases. As for Bawang Merah and his mother (Mbok Rondo Dadapan) are portrayed as mother and stepsister who are evil, cruel, unforgiving, and greedy for what Bawang Putih has. Meanwhile, Bawang Putih is shown as an obedient, patient, submissive, and weak woman.

The image that has been attached to these characters will be clarified by showing a side that has not been revealed by the previous storytellers. Therefore, in this study, the storyteller's point of view is changed, especially in the female characters who are told in this way. Changing the point of view provides space for the characters to talk about the reason they are portrayed as what has been developing so far. Thus, readers can recognize that folklore characters actually have good images. In the end, readers will no longer instil a bad image of folklore figures

\section{A. Bawang Merah Bawang Putih}

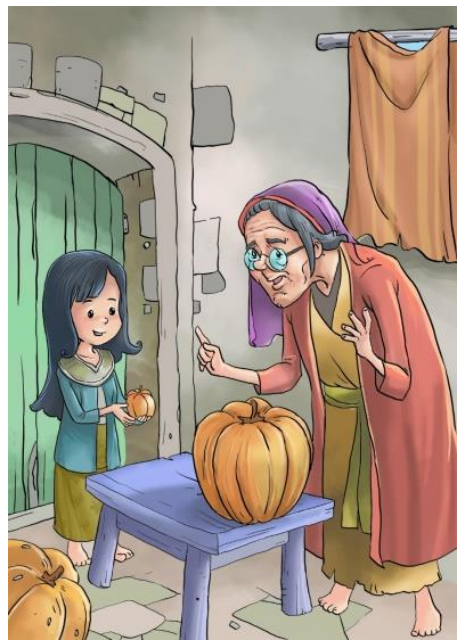

Fig. 1. Bawang Putih selects the small pumpkin.

The story of "Bawang Putih and Bawang Merah" sticks to the Figure 1 of a small pumpkin and a big pumpkin, an evil stepmother, and an evil stepsister.

Bawang Merah and Mbok Rondo Dadapan are placed as evil parent and stepsister. Mbok Rondo Dadapan and Bawang Merah have a bad image because they only have antagonistic traits, such as cruelty, rude, angry, and greedy. These assumptions are not entirely correct. The storyteller never prioritizes the voices of the characters Mbok Rondo Dadapan and Bawang Merah, even though there are reasons that make her acts as scary as the stories that have been circulating. In the 
reconstructed story script, the story emphasizes the point of view of Bawang Merah and Mbok Rondo Dadapan.

Mbok Rondo really loved Bawang Merah so she worked hard every day. she wanted the best for Bawang Merah.

The story opens by showing Mbok Rondo Dadapan's instinctive attitude as a mother and single parent who really loves her child (Bawang Merah), so she is willing to do anything for the happiness of the daughter.

... Mbok Rondo also accompanied Bawang Putih to have a chat. Mbok Rondo knew very well how the loneliness of a child after her parents died because her daughter, Bawang Merah, had felt this way.

Mbok Rondo has an empathetic attitude towards Bawang Putih's grief so that Mbok Rondo comes to position herself as a friend as well as a mother. From Mbok Rondo's attitude, Mbok Rondo is also a caring mother figure. It is not surprising that Mbok Rondo really loves her biological child, Bawang Merah.

Gradually, Bawang Putih's father felt Mbok Rondo's kindness and sincerity. With Bawang Putih's approval because Bawang Putih felt the same way, Bawang Putih's father married Bawang Merah's mother.

Bawang Putih as a female figure is not discriminated in making decisions. Bawang Putih is fully involved by her father in determining whether Mbok Rondo Dadapan is deserved to be married or not. Bawang Putih agrees with her father's request because Bawang Putih can logically assess Mbok Rondo likes her father does.

Bawang merah never did housework because all this time Mbok Rondo Dadapan really loved and pampered her.

From the start, Mbok Rondo is a loving mother figure. Mbok Rondo gives too deep and excessive levels of love and attention so that Mbok Rondo does not want trouble for her daughter

When rinsing, Bawang Putih slipped so that her stepmother's favourite cloth was washed away. Bawang Putih also ventured down the river to look for the cloth.

Stories are narrated from a perspective that does not weaken women. Bawang Putih is not careless but is experiencing adversity that is beyond her control. However, Bawang Putih chooses to take responsibility instead of giving up on losing her stepmother's cloth. she is looking for that cloth. She is dared to take the risk of venturing along the river flow until she can find her stepmother's cloth.

Because her stepmother's cloth had been found, Bawang Putih was so happy that she chose a small pumpkin. For Bawang Putih, a small pumpkin was enough because she didn't expect anything other than her stepmother's cloth to be found.

Bawang Putih represents a grateful female figure. She feels sufficient for what she has obtained. The stepmother's cloth and the little pumpkin are considered by her to be something very big. The attitude of Bawang Putih reflects the figure of a woman who is able to think rationally because it does not fulfil her lust desires. she is able to differentiate and control herself against needs and wants. At that time, she only needs her stepmother's cloth to be found, not get a big pumpkin. However, as a form of respect for the elderly grandmother, Bawang Putih accepts the gift.

As for Bawang merah, she has a reason why she chooses a large pumpkin. Apparently, she loves his mother and also wants to give her best. In addition, Bawang Merah wants to prove to her mother that she is able to get a large pumpkin.

\section{B. Sangkuriang}

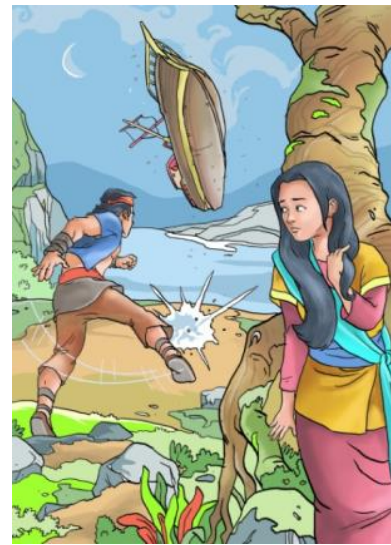

Fig. 2. Sangkuriang kicks the boat that he hasn't completed

Dayang Sumbi represents a smart woman. she has an ingenious way to thwart her marriage to Sagkuriang. Dayang Sumbi purposely choose a difficult request.

From the Figure 2, the most memorable thing from Sangkuriang's story is when Sangkuriang got angry because he didn't succeed in completing Dayang Sumbi's request. An angry Sangkuriang then kicked a large half-finished boat which later turned into Mount Tangkuban Perahu as we know it today.

In this story, the story is told from the voice of Dayang Sumbi. The story further raises the voice of Dayang Sumbi as a female character in the story. Dayang Sumbi's attitudes are told not to weaken her position as a woman.

Dayang Sumbi think hard. The Marriage cannot happen. With her cleverness, she asks Sangkuriang to build a dam on the Citarum River complete with a large boat in the middle. 


\section{Lutung Kasarung}

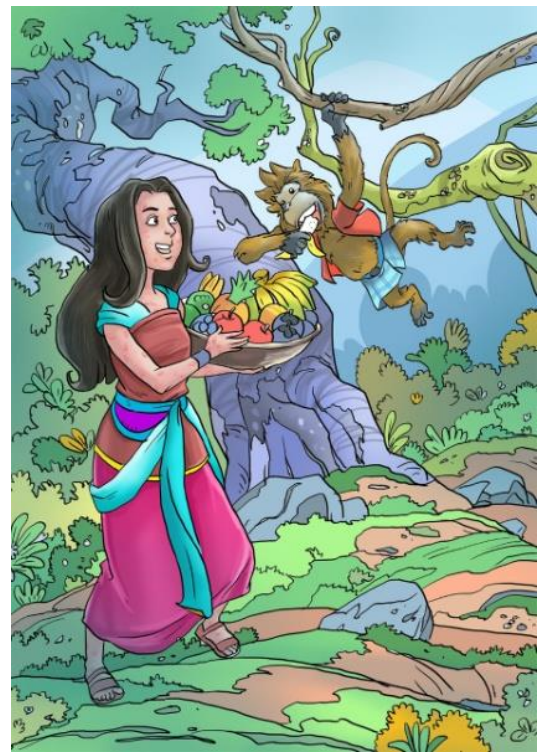

Fig. 3. Purbasari is exiled in the forest and makes a firens with monkeys.

After a long time on the throne, Prabu Tapa Agung appointed Purbasari to continue his leadership. The King had observed for ten years that Purbasari was deserved to replace him.

The Figure 3 shows Purbasari in the forest and made a friend with a monkey. After Purbasari was chosen by his father to continue leadership, Purbararang was angry. Purbararang did not accept it. Then, she injured Purbasari by causing a skin disease in Purbasari's body. In the end, Purbasari was considered to have brought disaster and had to be exiled in the forest.

The story of Lutung Kasarung contains a message of gender equality. Purbasari as a woman is given a place to lead. Purbasari corrects the stereotype that women should not lead. From the man point of view, in this case Prabu Tapa Agung, Prabu Tapa Agung sees Purbasari is worthy to lead. The view of Prabu Tapa Agung is certainly based on careful considerations. As a man, Prabu Tapa Agung trusts her. $\mathrm{He}$ does not ask Purbasari to marry so that the throne could be passed on to her husband, but Prabu Tapa Agung chooses Purbasari instead. Purbasari is considered to be able to make wise decisions.

\section{CONCLUSION}

Folklore is a cultural product that carries meaningful values. These values are used to instil moral education for future generations. Folk stories can fully provide inspiration and positive things for readers or connoisseurs. Therefore, the story is reconstructed with various considerations without changing the story line. If the story starts from the point of view of a male character, in this script, the folklore runs from the point of view of a female character so that it does not weaken the image of a woman. If the story runs from the point of view of the protagonist, in this script, the folklore runs from the point of view of the antagonist, so it does not create hatred towards women.

\section{REFERENCES}

[1] A. Agboola and K.C. Tsai, "Bring Character Education into Classroom.,” Eur. J. Educ. Res., vol. 1, no. 2, pp. 163-170, 2012.

[2] K. K. Frankel, B. L. C. Becker, M. W. Rowe, and P. D. Pearson, "From 'what is reading?' to what is literacy?,' J. Educ., vol. 196, no. 3, pp. 717, 2016.

[3] P.C. Akanwa, "Folk tales and the social development of the child," J. Niger. Lang. Cult. Vol, vol. 15, no. 1, pp. 99-114, 2014.

[4] E. Brown, J. Rosenthal, and N. Dynega, "Teaching Strategies to Develop a Family-School Literacy Partnership.,” Int. J. Whole Sch., vol. 14 , no. 1 , pp. 31-56, 2018.

[5] A. de Bruijn, "From representation to participation: Rethinking the intercultural educational approach to folktales," Child. Lit. Educ., vol. 50, no. 3, pp. 315-332, 2019.

[6] N.T. Onuora and O.E. Ebere, "LANGUAGE OF FOLKTALES FOR SUSTAINABLE AFRICAN MORAL LIFE," Language (Baltim)., vol. 9, no. 4, 2020.

[7] S.B. Olajide, "Folklore and Culture as Literacy Resources for National Emancipation.," Int. Educ. Stud., vol. 3, no. 2, pp. 200-205, 2010.

[8] J. Inggs, "Weak or Wily? Girls' Voices in Tellings and Retellings of African Folktales for Children," Child. Lit. Educ., pp. 1-15, 2020.

[9] N. Hosseinpour and A. Afghari, "Gender representation in Persian folktales for children,” Theory Pract. Lang. Stud., vol. 6, no. 1, pp. 111$118,2016$.

[10] D. Hapsarani, "Objektivikasi Perempuan dalam Tiga Dongeng Klasik Indonesia dari Sanggar Tumpal: Sangkuriang, Jaka Tarub, dan Si Leungli,” Paradig. J. Kaji. Budaya, vol. 7, no. 2, pp. 124-137, 2017.

[11] A. Zahro, "Women and the Indonesian Folktales : Gender Perspective," vol. 7, no. 2, pp. 89-99, 2020.

[12] U. Shaheen, N. Mumtaz, and K. Khalid, "Exploring Gender Ideology in Fairy Tales-A Critical Discourse Analysis," Eur. J. Res. Soc. Sci. Vol, vol. 7, no. 2, 2019.

[13] E.J. Blown and T.G.K. Bryce, "The enduring effects of early-learned ideas and local folklore on children's astronomy knowledge," Res. Sci. Educ., pp. 1-52, 2018.

[14] J.W. Creswell and C.N. Poth, Qualitative inquiry and research design: Choosing among five approaches. Sage publications, 2016.

[15] J.R. Fraenkel, N.E. Wallen, and H.H. Hyun, How to design and evaluate research in education, vol. 7. McGraw-Hill New York, 1993. 